\title{
Produksi dan Usahatani Padi Varietas Unggul Baru di Lahan Rawa Lebak Kabupaten Banyuasin Sumatera Selatan
}

\section{Production and Farming Of Rice New Superior Varieties in Swampy Lands Banyuasin District South Sumatra}

\section{Suparwoto Guwat*, Waluyo, dan Priatna Sasmita}

Balai Pengkajian Teknologi Pertanian Sumatera Selatan

*E-mail : suparwoto11@gmail.com

\begin{abstract}
One component of technology that has a real role in improving the production and quality of agricultural commodities is superior varieties, such as adaptive varieties and high yield potential in swampy land, especially rice. The purpose of the assessment is to obtain varieties that have high production, good plant growth and income information on rice farming in swampy land. The study was conducted in Sako Village, Banyuasin Regency, South Sumatera Province starting in the dry season of 2016. The varieties studied were 4 varieties: Inpari 15, Inpari 22, Inpari 30 and Inpara 4. The assessment was prepared based on a randomized block design (RAK). The observed variables were: plant height, number of productive tillers, panicle length, number of grains per panicle, percentage of grain of fill per panicle, and yield of dry grain harvest. Data analysis used variance analysis and continued with Duncan test at $5 \%$ level. The results showed that the production of Inpari 15, Inpari 22, Inpari 30 and Inpara 4 was 4.9 tons $\mathrm{gkp} / \mathrm{ha}, 6.8$ tons gkp / ha, 6.1 tons $\mathrm{gkp} / \mathrm{ha}$, 7.0 tons gkp / ha. Financially, the use of Inpari 22, Inpari 30 and Inpara 4 superior varieties is feasible to develop and benefit with the $B C$ ratio $>1.0$.
\end{abstract}

Keywords: Rice, production, swampy land, farming

Disubmit : 20 Agustus 2017, Diterima : 01 Desember 2017, Disetujui :08 Desember 2017

\section{PENDAHULUAN}

Lahan lebak merupakan salah satu alternatif untuk areal produksi tanaman padi baik masa kini maupun masa yang akan datang, karena menyempitnya lahan sawah akibat alih fungsi lahan menjadi lahan non pertanian seperti perumahan, pabrik dan jalan lebih kurang 40 ribu ha per tahun, maka pemerintah harus memanfaatkan lahan suboptimal tersebut untuk menggantinya dengan harapan dapat mengimbangi kenaikan kebutuhan beras akibat bertambah jumlah penduduk (Supartopo et al , 2010). Luas lahan rawa lebak di Indonesia diperkirakan seluas 13,3 juta ha yang terdiri dari 4,2 juta ha rawa lebak dangkal, 6,07 juta ha lahan rawa lebak tengahan dan 3,0 juta ha rawa lebak dalam, lahan tersebut tersebar di Sumatera, Kalimantan dan Irian Jaya (Khairullah et al., 2009). Peningkatan kebutuhan pangan secara ekstensifikasi maupun intensifikasi diarahkan di luar pulau Jawa karena memungkinkan untuk peningkatan tersebut diantaranya Provinsi Sumatera Selatan.

Pada tahun 2014 luas panen padi di Sumatera Selatan mencapai 810.900 ha dengan rata-rata produktivitas 4.5 ton/ha dan secara nasional sudah mencapai 5.1 ton/ha (Badan Pusat Statistik Indonesia, 2015). Hal ini disebabkan oleh teknologi yang digunakan petani masih relatif sederhana, masih banyak penggunaan varietas lokal, varietas unggul tidak berlabel, dan penggunaan pupuk sangat tergantung dengan 
keadaan ekonomi petani. Selain itu rendahnya produktivitas disebabkan juga oleh penggunaan varietas yang sama dalam jangka waktu yang lama dan penurunan kualitas sumberdaya lahan.

Arifin et al., (1999) dalam Subaidi et al., (2012) mengatakan bahwa varietas yang ditanam secara terus-menerus dalam skala luas akan menyebabkan hama/penyakit (strain) baru sehingga dapat menurunkan resistensi tanaman, berkurangnya produksi bahkan gagal panen. Banjir dan tinggi genangan air merupakan faktor penghambat dan bahaya bagi pertumbuhan tanaman padi. Selain itu, kesuburan tanah yang rendah, kemasaman tanah, keracunan dan defisiensi hara juga merupakan masalah yang penting di lahan rawa lebak. Kemudian hama dan penyakit misalnya hama tikus, keong mas, kepik, penggerek batang, walang sangit. Penyakitnya yaitu penyakit blas, bercak daun coklat, juga merupakan faktor penghambat.

Pada umumnya petani menanam padi hanya satu kali dalam setahun pada musim kemarau, penanaman padi dilakukan setelah air pada rawa lebak dangkal mulai menyurut dan selanjutnya diikuti oleh lebak tengahan dan dalam. Bila pada lahan lebak dalam, genangan air masih dalam biasanya tidak ditanami. Penanaman varietas padi yang adaptif pada lahan sawah lebak adalah salah satu upaya penting yang perlu ditempuh sehingga produktivitasnya lebih tinggi, tahan terhadap hama dan penyakit utama dan mempunyai kualitas beras yang baik. Dikemukakan oleh Mugiono et al., (2010) bahwa teknologi varietas lebih aman, dan lebih ramah lingkungan serta murah harganya bagi petani.

Terbatasnya varietas padi rawa menyebabkan Balai Besar Penelitian Tanaman Padi terus membuat galur-galur untuk padi rawa guna untuk meningkatkan produksi. Dikemukakan oleh Jonharnas et al. (2009), galur yang memiliki keunggulan yang baik dari varietas yang berkembang di petani akan dapat diterima lebih cepat oleh konsumen bila sesuai dengan preferensi konsumen. Hasil penelitian sebelumnya, varietas unggul padi yang ditanam di lahan rawa lebak Kabupaten Banyuasin Sumsel seperti Ciherang, Inpara 2 dan Inpara 1 dapat tumbuh baik dengan produksi 6,5-7,4 ton gkp/ha pada MK 2009 (Suprihatno, et al, 2010).

Hasil kajian di Desa Epil, Kecamatan Lais Kabupaten Musi Banyuasin pada MK 2013 bahwa Inpari 4, Inpari 10 dan Inpari 13 disukai petani dengan hasil rata-rata 4,8 ton gkg/ha (Suparwoto, 2014). Dengan demikian varietas unggul tersebut perlu dikaji di lahan rawa lebak. Adapun tujuannya untuk mendapatkan varietas yang memiliki produksi tinggi, dan pertumbuhan yang baik dan informasi pendapatan usahatani padi di lahan rawa lebak.

\section{METODE PENELITIAN}

Pengkajian ini dilaksanakan di Desa Sako, Kabupaten Banyuasin, Provinsi Sumatera Selatan dimulai pada musim kemarau. Bahan yang dibutuhkan antara lain: benih padi varietas Inpari 15, Inpari 22, Inpari 30 dan Inpara 4 berlabel ungu, pupuk urea, SP-36, KCl, pestisida, herbisida dan terpal. Selain itu alat yang dibutuhkan antara lain : hand traktor, meteran, timbangan, parang, cangkul, sprayer. Varietas yang dikaji sebanyak 4 varietas terdiri dari Inpari 15, Inpari 22, Inpari 30 dan Inpara 4. Penelitian disusun berdasarkan rancangan acak kelompok (RAK) di mana 5 petani sebagai ulangan, luasan pengkajian satu hektar, jarak tanam $25 \mathrm{~cm} \times 25 \mathrm{~cm}$, umur bibit $30 \mathrm{HSS}$, ditanam 2-3 bibit/rumpun. Pupuk yang digunakan $150 \mathrm{~kg}$ Urea, $100 \mathrm{~kg} \mathrm{SP}-36$ dan $100 \mathrm{~kg} \mathrm{KCl} / \mathrm{ha}$. Pemupukan dilakukan 2 kali yaitu pada umur 0-7 hari setelah tanam (HST) dengan takaran $75 \mathrm{~kg}$ urea, $100 \mathrm{~kg} \mathrm{SP}-36$ dan $100 \mathrm{~kg} \mathrm{KCl} / \mathrm{ha}$ dan pada umur 4 minggu setelah tanam (MST) dengan takaran $75 \mathrm{~kg}$ urea/ha, diberikan secara disebar.

Persemaian dilakukan dua kali pindah karena permukaan genangan masih tinggi. Pemberantasan hama dan penyakit dilakukan apabila diperlukan sesuai keadaan di lapangan. Penyulaman dilakukan seminggu setelah tanam, sedangkan penyiangan pertama dan kedua dilakukan masing-masing pada 30 hari dan 60 hari setelah tanam. Bila perlu dilakukan penyiangan ketiga, tergantung keadaan di lapangan. Penentuan sampel dilakukan secara acak, masing-masing varietas sebanyak 5 tanaman. Peubah yang diamati adalah : tinggi tanaman, jumlah anakan produktif, panjang malai, jumlah gabah per malai, persentase gabah isi per malai, dan hasil gabah kering panen/petak (5m x 5m) kemudian dikonversi ke dalam ton/ha, sarana 
produksi dan tenaga kerja. Analisis data menggunakan analisis sidik ragam dan dilanjutkan dengan uji Duncan pada taraf $5 \%$. Analisis usahatani yaitu analisis penerimaan dan pendapatan, dan analisis imbangan pendapatan atas biaya (B/C) (Malian, 2004):

$$
\mathrm{B} \text { C ratio }=(\mathrm{RAVC}) / \mathrm{TVC}
$$

Keterangan :

$$
\begin{array}{llll}
\mathrm{BC} \text { ratio } & =\text { Nisbah pendapatan terhadap biaya } & \mathrm{TVC} & =\text { Biaya total }(\mathrm{Rp} / \mathrm{ha} / \mathrm{musim}) \\
\mathrm{P} & =\text { Harga jual padi }(\mathrm{Rp} / \mathrm{kg}) & \mathrm{RAVC} & =(\mathrm{Q} \times \mathrm{P})-\mathrm{TVC} \\
\mathrm{Q} & =\text { Total produksi padi }(\mathrm{kg} / \mathrm{ha} / \text { musim }) & &
\end{array}
$$

\section{HASIL DAN PEMBAHASAN}

Tinggi tanaman dari Inpari 15, Inpari 22, Inpari 30 dan Inpara 4 bervariasi dari 99,9 cm hingga 115,7 $\mathrm{cm}$, varietas Inpara 4 memiliki tinggi tanaman 115,7 cm lebih tinggi dari varietas lainnya dan terpendek pada Inpari 22 yaitu 99,9 cm, sehingga berdasarkan uji statistik varietas Inpara 4 berbeda nyata dengan Inpari 15, Inpari 22 dan Inpari 30. Kemudian Inpari 30 tidak berbeda nyata dengan Inpari 15. (Tabel 1). Semakin tinggi tanaman semakin tinggi kecenderungan untuk rebah. Varietas yang memiliki pertumbuhan tinggi tanaman yang sedang $(90-115 \mathrm{~cm})$ serta karakter batang yang kokoh tidak akan mudah rebah. Dikemukakan oleh Asaad dan Warda (2010), tinggi tanaman merupakan salah satu kriteria seleksi pada tanaman padi, tetapi dengan pertumbuhan tanaman yang tinggi tidak menjamin tingkat produktivitasnya.

Jumlah anakan produktif dari Inpari 15, Inpari 22, Inpari 30 dan Inpara 4 bervariasi dari 12,8 batang hingga 20,7 batang, jumlah anakan terbanyak dicapai oleh varietas Inpari 22 yaitu 20,7 batang dan yang sedikit 12,8 batang pada Inpari 15. Berdasarkan hasil statistik bahwa jumlah anakan produktif Inpari 22, tidak berbeda sangat nyata dengan Inpari 30 dan Inpara 4 tetapi berbeda nyata dengan Inpari 15 (Tabel 1).

Panjang malai dari empat varietas tersebut rata-rata $24,9 \mathrm{~cm}$ hingga $26,4 \mathrm{~cm}$, Inpari 22 mempunyai panjang malai lebih panjang dari lainnya yaitu $26,4 \mathrm{~cm}$ dan terpendek dimiliki Inpari 30 yaitu $24,9 \mathrm{~cm}$. Berdasarkan hasil penelitian, panjang malai dari Inpari 22, dan Inpari 15 tidak berbeda nyata tetapi berbeda nyata dengan Inpari 30 dan Inpara 4 (Tabel 1). Dikemukakan oleh Waluyo et al.,(2015) bahwa panjang malai juga merupakan parameter pendukung untuk potensi hasil. Jumlah gabah per malai yang banyak dimiliki oleh Inpara 4, yaitu 211,6 butir dan yang sedikit dimiliki oleh Inpari 22, yaitu 141,1 butir, tetapi secara statistik jumlah gabah per malai dari Inpara 4 berbeda nyata dengan Inpari 15, Inpari 22, dan Inpari 30, sedangkan Inpari 22 tidak berbeda nyata dengan Inpari 30.

Tabel 1. Rata-rata tinggi tanaman, jumlah anakan produktif, panjang malai, jumlah gabah/malai, persentase gabah isi/malai dan produktivitas gabah.

\begin{tabular}{clcccccc}
\hline No & Varietas & $\begin{array}{c}\text { Tinggi } \\
\text { tanaman } \\
(\mathrm{cm})\end{array}$ & $\begin{array}{c}\text { Jlh anakan } \\
\text { produktif } \\
(\mathrm{btg})\end{array}$ & $\begin{array}{c}\text { Panjang } \\
\text { malai } \\
(\mathrm{cm})\end{array}$ & $\begin{array}{c}\text { Jumlah } \\
\text { gabah/malai } \\
(\mathrm{btr})\end{array}$ & $\begin{array}{c}\text { Persentase } \\
\text { gabah isi/malai } \\
(\%)\end{array}$ & $\begin{array}{c}\text { produktivitas } \\
\text { gabah } \\
(\mathrm{gkp} / \mathrm{ha})\end{array}$ \\
\hline 1 & Inpari 15 & $105,6 \mathrm{~b}$ & $12,8 \mathrm{a}$ & $25,9 \mathrm{~b}$ & $171,6 \mathrm{~b}$ & $81,3 \% \mathrm{~b}$ & $4,9 \mathrm{a}$ \\
2 & Inpari 22 & $99,9 \mathrm{a}$ & $20,7 \mathrm{~b}$ & $26,4 \mathrm{c}$ & $141,1 \mathrm{a}$ & $87,3 \% \mathrm{c}$ & $6,8 \mathrm{c}$ \\
3 & Inpari 30 & $107,7 \mathrm{~b}$ & $17,7 \mathrm{~b}$ & $24,9 \mathrm{a}$ & $156,0 \mathrm{~b}$ & $89,9 \% \mathrm{c}$ & $6,1 \mathrm{~b}$ \\
4 & Inpara 4 & $115,7 \mathrm{c}$ & $17,2 \mathrm{~b}$ & $25,0 \mathrm{~b}$ & $211,6 \mathrm{c}$ & $75,3 \% \mathrm{a}$ & $7,0 \mathrm{c}$ \\
& Rata-rata & 107,2 & 17,1 & 25,5 & 170 & $83,5 \%$ & 6,2 \\
\hline
\end{tabular}

Keterangan : Angka-angka yang diikuti oleh huruf yang sama pada kolom yang sama berarti tidak berbeda nyata pada uji Duncan taraf 5\%

Persentase gabah isi dari empat varietas yang dikaji bervariasi antara 75,3 \% hingga 89,9\%. Persentase gabah isi terbanyak dicapai oleh Inpari 30 yaitu 89,9\% (135 butir) dan sedikit oleh Inpara 4 yaitu 75,3\%(159 butir). Berdasarkan uji statistik bahwa persentase gabah isi per malai dari Inpari 30 (89,9\%) 
berbeda sangat nyata dengan varietas lainnya. (Tabel 1). Ramli (1993) dalam Waluyo et al., (2015), empat komponen hasil, yaitu jumlah anakan produktif, jumlah gabah per malai, persentase gabah hampa per malai dan gabah isi per malai serta bobot 1000 butir gabah isi merupakan komponen pendukung produksi gabah.

Hasil gabah tertinggi dicapai oleh Inpara 4 yaitu 7,0 ton gkp/ha sedangkan hasil gabah terendah 4,9 ton gkp/ha oleh Inpari 15 . Hasil gabah Inpara 4 tidak berbeda nyata dengan Inpari 22 tetapi berbeda nyata dengan Inpari 15 dan Inpari 30. Berdasarkan reaksi ketahanan terhadap penyakit blas maka Inpari 22 dan Inpara 4 tergolong tahan penyakit blas, Inpari 15 tergolong sedang dan Inpari 30 tergolong agak tahan penyakit blas (Tabel 2). Dikemukakan oleh Dede Rohanaya (2012), produksi gabah ditentukan oleh komponen hasilnya dan komponen tersebut ditentukan oleh faktor genetik dari varietas dan faktor lingkungan seperti iklim, hara, tanah dan air

Tabel 2. Reaksi ketahanan terhadap penyakit blast.

\begin{tabular}{ccccc}
\hline No & Varietas & Berat serangan & Skala & Reaksi ketahanan \\
\hline 1 & Inpari 15 & $11-15 \%$ & 5 & sedang \\
2 & Inpari 22 & $<5 \%$ & 1 & tahan \\
3 & Inpari 30 & $5-10 \%$ & 3 & agak tahan \\
4 & Inpara 4 & $<5 \%$ & 1 & tahan \\
\hline
\end{tabular}

Keterangan : Skala $1=$ tahan skala $3=$ agak tahan skala $5=$ sedang

Analisis Usaha Tani. Biaya produksi tidak termasuk biaya jemur karena hasil panen dibeli oleh ketua kelompok penangkar benih dengan harga Rp 4.300/kg gkp. Pendapatan rata-rata selama satu musim tanam usahatani padi adalah Rp. 14.300.000/ha/musim, yang diperoleh dari selisih antara penerimaan dengan total biaya produksi. Rata-rata $\mathrm{BC}$ ratio untuk empat varietas padi yang diteliti sebesar 1,14, nilai ini diperoleh dari hasil bagi antara rata-rata pendapatan usahatani padi dengan rata-rata total biaya usahatani tersebut. Dari kriteria yang digunakan adalah jika $\mathrm{BC}$ ratio $\geq 1$ usahatani padi layak diusahakan. Nilai BC ratio ini menggambarkan bahwa setiap 1 rupiah pengeluaran dalam usahatani padi yang dilakukan tersebut menghasilkan 1,14 satuan pendapatan. Pendapatan terbesar diperoleh dari usahatani tanaman varietas Inpara 4 yaitu Rp17.420.000/ha/musim, Inpari 22 dengan pendapatan Rp 16.640.000/ha/musim dan Inpari 30 dengan pendapatan Rp 13.910.000/ha/musim yang ditunjukkan nilai $\mathrm{BC}$ ratio > 1,0 (Tabel 3).

Tabel 3. Biaya usahatani padi seluas 1 hektar di Desa Sako, Kecamatan Rambutan Kabupaten Banyuasin, MK 2016

\begin{tabular}{lccccc}
\hline Varietas & $\begin{array}{c}\text { Produksi (kg } \\
\text { gkp/ha) }\end{array}$ & $\begin{array}{c}\text { Biaya produksi } \\
(\mathrm{Rp})\end{array}$ & Penerimaan (Rp) & Pendapatan (Rp) & BC ratio \\
\hline Inpari 15 & 4900 & 11.840 .000 & 21.070 .000 & 9.230 .000 & 0,78 \\
Inpari 22 & 6800 & 12.600 .000 & 29.240 .000 & 16.640 .000 & 1,32 \\
Inpari 30 & 6100 & 12.320 .000 & 26.230 .000 & 13.910 .000 & 1,12 \\
Inpara 4 & 7000 & 12.680 .000 & 30.100 .000 & 17.420 .000 & 1,37 \\
\hline Rata-rata & 6200 & 12.360 .000 & 26.660 .000 & 14.300 .000 & 1,14 \\
\hline
\end{tabular}

\section{KESIMPULAN}

Tanaman padi varietas Inpari 15, Inpari 22, Inpari 30 dan Inpara 4 dapat beradaptasi pada lahan rawa lebak dengan produksi tertinggi dicapai oleh Inpara 4 yaitu 7,0 ton gkp/ha, dan tidak berbeda nyata Inpari 22 yaitu 6,8 ton gkp/ha. Varietas yang terpilih yaitu Inpari 22, Inpari 30 dan Inpara 4 berdasarkan ketahanan terhadap penyakit blas. Secara financial tiga varietas tersebut layak dikembangkan dan menguntungkan dengan nilai $\mathrm{BC}$ ratio $>1,0$. 


\section{DAFTAR PUSTAKA}

Asaad, M dan Warda. 2010. Keragaan Beberapa Galur Harapan Padi Sawah di Kabupaten Sidrap, Sulawesi Selatan.Prosiding Seminar Ilmiah Hasil Penelitian Padi Nasional.Dalam :Supriatno. B, Aan Andang Darajat, Satoto, Baehaki dan Sudir (ED). Balai Besar Penelitian Tanaman Padi. Badan Litbang Pertanian. Kementerian Pertanian. P, 11-22.

Badan Pusat Statistik Indonesia. 2015. Statistik Indonesia. Badan Pusat Statistik Indonesia. Jakarta.

Dede Rohayana dan R. Asnawi. 2012. Keragaan hasil varietas unggul Inpari 7 ,Inpari 10 dan Inpari 13 melalui pendekatan pengelolaan tanaman terpadu (PTT) di Kabupaten Pesawaran. Prosiding inovasi hasil penelitian dan pengkajian teknologi pertanian (hlm.119-128). Desember 2012. Balai Pengkajian Teknologi Pertanian. Lampung.

Jonharnas, Novia, C, Syahrul, Z. 2009. Penampilan beberapa galur harapan padi sawah di Deli Serdang, Sumatera Utara. Prosiding Seminar Nasional Hasil Penelitian Padi: Buku 1 : inovasi teknologi padi untuk mempertahankan swasembada dan mendorong ekspor beras. BB Padi (Pusat/Puslit.Puslitbang/Balai Besar). p. 115-121.

Khairullah Izhar, M.Saleh dan Mawardi. 2009. Penampilan galur padi WAR 115-1-2-4-2-4-B-B-4 di lahan lebak tengahan Kalimatan Selatan. Prosiding Seminar Nasional Padi 2008: Inovasi Teknologi Padi Mengantisipasi Perubahan Iklim Global Mendukung Ketahanan Pangan. Buku 1 (hlm.127-138). 2324 Juli 2008. Balai Besar Penelitian Tanaman Padi. Badan Litbang Pertanian.Sukamandi.

Malian, A. Husni. 2004. Analisis ekonomi usahatani dan kelayakan finansial teknologi pada skala pengkajian. Pusat Penelitian dan Pengembangan Sosial Ekonomi Pertanian dan Proyek Pengkajian Teknologi Pertanian Partisipatif (The Participating Development of technology Transfer Project (PAATP). Badan Penelitian dan Pengembangan Pertanian.

Mugiono, Sherly Rahayu, Jeany P. Mandang. 2010. Penggunaan teknik mutasi radiasi untuk perbaikan bentuk dan umur padi varietas superwin. Prosiding Seminar Nasional Hasil Penelitian padi 2009, Buku 1(hlm. 161-170). 20 Oktober 2009. Balai Besar Penelitian Tanaman Padi. Badan Litbang Pertanian Sukamandi.

Supartopo, Aris H, dan Bambang K. 2010. Galur harapan padi untuk lahan rawa dan rawan banjir. Prosiding Seminar Nasional Hasil Penelitian Padi 2009. Buku 1 (hlm. 141-150). 20 Oktober 2009. Balai Besar Penelitian Tanaman Padi, Badan Litbang Pertanian. Sukamandi.

Suprihatno, B., Daradjat, A.A., Satoto, Suwarno, Lubis, E., Baehaki, S.E., Sudir, Indrasari, S.D., Wardana, I.P, dan I.M J. Mejaya. 2011. Diskripsi Varietas Pad (Edisi Revisi). Badan Penelitian dan Pengembangan Pertanian. Balai Besar Penelitian Tanaman Padi : 126.

Achmad Subaidi, Enti Sirnawati, Astrina Yulianti, Yovita A.D, dan Istriningsih (Ed). Prosiding Seminar Nasional Inovasi Pertanian Spesifik Lokasi (hlm.288-296). 6-7 Juni 2012. Balai Besar Pengkajian dan Pengembangan Teknologi Pertanian. Medan.

Suparwoto, Waluyo dan Usman Setiawan. 2014. Keragaan varietas Inpari pada lahan lebak tengahan di Desa Epil, Kabupaten Musi Banyuasin, Sumatera Selatan. Prosiding Seminar Nasional Pengembangan Teknologi Pertanian (hlm. 43-49). 24 Mei 2014. Lampung: Polinela.

Waluyo, Yanter Hutapea dan Suparwoto. 2015. Pengkajian varietas unggu baru padi (Inpari) di lahan sawah tadah hujan, Kabupaten Ogan Komering Ilir Sumatera Selatan. Prosiding Seminar Nasional Hasil Penelitian Padi 20014. Buku 2 (hlm.631-642). 19 Agustus 2014. Balai Besar Penelitian Tanaman Padi, Badan Litbang Pertanian. Sukamandi. 